\title{
Electrocoagulation for COD and diesel removal from oily wastewater
}

\author{
S. Safari ${ }^{1}$ M. Azadi Aghdam ${ }^{1} \cdot$ H.-R. Kariminia ${ }^{1}$
}

Received: 8 January 2015/Revised: 12 May 2015/Accepted: 13 July 2015/Published online: 21 August 2015

(C) Islamic Azad University (IAU) 2015

\begin{abstract}
This study investigated the diesel and COD removal from oily wastewater by electrocoagulation. Experiments were conducted in a 2-1 reactor using aluminum and iron electrodes. Effects of different parameters including $\mathrm{pH}$ (3-11), time $(10-60 \mathrm{~min})$, voltage (4.5-10.5 V), supporting electrolyte $(\mathrm{NaCl}$ concentration), electrode material and initial diesel concentration $(3500-11,000 \mathrm{mg} / \mathrm{L})$ were studied in order to evaluate the efficiency of electrocoagulation. Furthermore, the consumption of energy and the amount of sludge produced by this method were evaluated. The highest removal efficiency (COD removal of $99.1 \pm 0.2 \%$ and diesel removal of $98.8 \pm 0.2 \%$ ) was observed under the following conditions: $\mathrm{pH} 7,40 \mathrm{~min}, 10.5 \mathrm{~V}, \mathrm{NaCl}$ concentration of $0.5 \mathrm{~g} /$ $\mathrm{L}$, diesel concentration of $3500 \mathrm{mg} / \mathrm{L}$. The consumption of energy was estimated to be $6.47 \mathrm{kWh} / \mathrm{m}^{3}$, and the amount of sludge generated was $1995 \mathrm{mg} / \mathrm{L}$. The results demonstrated that the electrocoagulation is a feasible technique for treatment of heavily contaminated petroleum refinery wastewater.
\end{abstract}

Keywords COD removal - Diesel removal . Electrocoagulation · GC-MS · Oily wastewater

H.-R. Kariminia

kariminia@sharif.ir

1 Department of Chemical and Petroleum Engineering, Sharif University of Technology, P.O. Box: 11155-9465, Tehran, Iran

\section{Introduction}

\section{Petroleum refineries' wastewater}

Large quantity of water is used by petroleum refineries for different objectives such as distillation, hydrotreating, desalting and cooling systems (Yavuz et al. 2010); hence, they create considerable quantities of wastewater. The features of the generated wastewater depend strongly on the process configuration (Rasheed et al. 2011).

Petroleum refineries' wastewater has high concentrations of aliphatic and aromatic petroleum hydrocarbons (El-Naas et al. 2009; Sun et al. 2008). Refinery effluents possess contaminants such as cyanide, oil, phenols, benzene, sulfide, ammonia and heavy metals. This wastewater is normally rich in biological oxygen demand (BOD) and chemical oxygen demand (COD) (Rasheed et al. 2011; Verma et al. 2013), which usually have damaging and harmful effects on plants, sea, river as well as surface and groundwater sources (El-Naas et al. 2009; Sun et al. 2008). Facilities are required to reduce the concentration of organic contaminants in their wastewater to a value susceptible to microbial degradation prior to the final biological treatment and purification stage. These pretreatment units are normally consisting of ultrafiltration, adsorption, coagulant and coagulant aides and electrochemical processes (El-Naas et al. 2009).

\section{Electrocoagulation}

Electrocoagulation (EC) is one of the novel methods for water and wastewater treatment (Chafi et al. 2011). The EC process possesses several advantages such as easy operation, short treatment time, low sludge production and no chemical requirement (Gengec et al. 2012). The EC is a technology 
that has been effectively used to treat industrial wastewater containing different pollutants such as arsenic, phosphate, boron, dyes and viruses. Furthermore, it has been effective in breaking oil emulsions in water and treating paper mill effluent, olive mill effluent, landfill leachate and dairy effluent (Bensadok et al. 2008; Irdemez et al. 2006; Katal and Pahlavanzadeh 2011; Khoufi et al. 2007; Li et al. 2011; Azadi Aghdam et al. 2015; Phalakornkule et al. 2010; Sengil and Ozacar 2006; Tchamango et al. 2010; Wan et al. 2011; Yilmaz et al. 2008; Zhu et al. 2005; Amani-Ghadim et al. 2013).

Few studies have investigated the removal of hydrocarbons using EC process. Moussavi et al. (2011) used EC process for removing hydrocarbons from contaminated groundwater. Effects of $\mathrm{pH}$, electrode material, current density and treatment time are investigated, and the removal efficiency of $95.1 \%$ for total hydrocarbon was achieved in optimized conditions ( $\mathrm{pH}$ of neutral, electrode arrangement of steel-aluminum as anode-cathode and current density of $18 \mathrm{~mA} / \mathrm{cm}^{2}$ ). Karhu et al. (2012) studied bench-scale treatment of 0.6 and $2 \%$ bio oil-in-water and synthetic oil-in-water emulsions. No significant difference was detected in using stainless steel or aluminum electrodes. Furthermore, turbidity, COD and TOC removals of 75-100, 25-95 and 20-75\% were achieved, respectively.

In an EC process, the coagulating ions are generated in situ involving three stages (a) electrolytic reactions at electrode surfaces, (b) formation of coagulants in aqueous phase and (c) adsorption of soluble or colloidal pollutants on coagulants, which are removed by sedimentation or flotation (Kobya et al. 2003). Iron (Fe) and aluminum (Al) have been extensively applied as a sacrificial electrode in the EC process (Gengec et al. 2012, Kobya et al. 2006). Sacrificial electrode dissolves from the anode creating corresponding metal ions. These ions hydrolyze to polymeric iron or aluminum oxyhydroxides, which are the coagulating agents (Gengec et al. 2012).

\section{Reactions and mechanisms}

The major reaction at the anode when aluminum electrode is applied in the EC process is as follows:

$\mathrm{Al}_{(\mathrm{s})} \rightarrow \mathrm{Al}_{(\mathrm{aq})}^{3+}+3 \mathrm{e}^{-}$

In addition, oxygen evolution can compete with aluminum dissolution at the anode by the following reaction:

$2 \mathrm{H}_{2} \mathrm{O}_{(\mathrm{l})} \rightarrow \mathrm{O}_{2(\mathrm{~g})}+4 \mathrm{H}_{(\mathrm{aq})}^{+}+4 \mathrm{e}^{-}$

At the cathode, hydrogen evolution occurs by the following reaction. It contributes to floatation of the flocculated particles to the surface of the wastewater.
$3 \mathrm{H}_{2} \mathrm{O}_{(\mathrm{l})}+3 \mathrm{e}^{-} \rightarrow \frac{3}{2} \mathrm{H}_{2(\mathrm{~g})}+3 \mathrm{OH}_{(\mathrm{aq})}^{-}$

At high $\mathrm{pH}$ values, generated $\mathrm{OH}^{-}$at the cathode attacks the cathode by the following reaction (Gengec et al. 2012; Kobya et al. 2003, 2006):

$2 \mathrm{Al}+6 \mathrm{H}_{2} \mathrm{O}+2 \mathrm{OH}^{-} \rightarrow 2 \mathrm{Al}(\mathrm{OH})_{4}^{-}+3 \mathrm{H}_{2(\mathrm{~g})}$

Electrode reactions generate $\mathrm{Al}_{(\mathrm{aq})}^{3+}$ and hydroxyl ions [Reactions (1) and (4)] to form different monomericpolymeric species such as $\mathrm{Al}(\mathrm{OH})_{4}^{-}, \quad \mathrm{Al}_{13}(\mathrm{OH})_{34}^{5+}$, $\mathrm{Al}_{7}(\mathrm{OH})_{17}^{4+}, \quad \mathrm{Al}_{8}(\mathrm{OH})_{20}^{4+}, \quad \mathrm{Al}_{2}(\mathrm{OH})_{2}^{4+}, \quad \mathrm{Al}(\mathrm{OH})^{2+}$, $\mathrm{Al}(\mathrm{OH})_{2}^{+}, \quad \mathrm{Al}_{13} \mathrm{O}_{4}(\mathrm{OH})_{24}^{7+}, \quad \mathrm{Al}_{6}(\mathrm{OH})_{15}^{3+}$ which transform primarily into $\mathrm{Al}(\mathrm{OH})_{3(\mathrm{~s})}$ and eventually polymerize to $\mathrm{Al}_{\mathrm{n}}(\mathrm{OH})_{3 \mathrm{n}}$ [Reactions (5) and (6)] in the solution (Gengec et al. 2012; Kobya et al. 2006):

$\mathrm{nAl}(\mathrm{OH})_{3} \rightarrow \mathrm{Al}_{\mathrm{n}}(\mathrm{OH})_{3 \mathrm{n}}$

$\mathrm{Al}^{3+}+3 \mathrm{H}_{2} \mathrm{O} \rightarrow \mathrm{Al}(\mathrm{OH})_{3(\mathrm{~s})}+3 \mathrm{H}^{+}$

Formed amorphous $\mathrm{Al}(\mathrm{OH})_{3(\mathrm{~s})}$ have great surface areas and contribute to quick adsorption of soluble organic compounds and also trapping the colloidal particles which are easily separated from aqueous medium by $\mathrm{H}_{2}$ flotation or sedimentation (Kobya et al. 2006). The concentration of hydrolyzed aluminum species relies on the $\mathrm{pH}$ and aluminum concentration (Gengec et al. 2012).

Iron produces $\mathrm{Fe}(\mathrm{OH})_{\mathrm{n}}$ where $n=2$ or 3 upon oxidation in an electrolytic system. Two mechanisms have been suggested for the formation of $\mathrm{Fe}(\mathrm{OH})_{\mathrm{n}}$ (Gendel and Lahav 2010; Mollah et al. 2001). The first mechanism includes the reactions (7)-(10):

At the anode:

$4 \mathrm{Fe}_{(\mathrm{s})} \rightarrow 4 \mathrm{Fe}_{(\mathrm{aq})}^{2+}+8 \mathrm{e}^{-}$

$4 \mathrm{Fe}_{(\mathrm{aq})}^{2+}+10 \mathrm{H}_{2} \mathrm{O}_{(\mathrm{l})}+\mathrm{O}_{2(\mathrm{~g})} \rightarrow 4 \mathrm{Fe}(\mathrm{OH})_{3(\mathrm{~s})}+8 \mathrm{H}_{(\mathrm{aq})}^{+}$

At the cathode:

$8 \mathrm{H}_{(\mathrm{aq})}^{+}+8 \mathrm{e}^{-} \rightarrow 4 \mathrm{H}_{2(\mathrm{~g})}$

Overall:

$4 \mathrm{Fe}_{(\mathrm{s})}+10 \mathrm{H}_{2} \mathrm{O}_{(\mathrm{l})}+\mathrm{O}_{2(\mathrm{~g})} \rightarrow 4 \mathrm{Fe}(\mathrm{OH})_{3(\mathrm{~s})}+4 \mathrm{H}_{2(\mathrm{~g})}$

The second mechanism includes the reactions (11)-(14): At the anode:

$\mathrm{Fe}_{(\mathrm{s})} \rightarrow \mathrm{Fe}_{(\mathrm{aq})}^{2+}+2 \mathrm{e}^{-}$

$\mathrm{Fe}_{(\mathrm{aq})}^{2+}+2 \mathrm{OH}_{(\mathrm{aq})}^{-} \rightarrow \mathrm{Fe}(\mathrm{OH})_{2(\mathrm{~s})}$

At the cathode: 
$2 \mathrm{H}_{2} \mathrm{O}_{(\mathrm{l})}+2 \mathrm{e}^{-} \rightarrow \mathrm{H}_{2(\mathrm{~g})}+2 \mathrm{OH}_{(\mathrm{aq})}^{-}$

Overall:

$\mathrm{Fe}_{(\mathrm{s})}+2 \mathrm{H}_{2} \mathrm{O}_{(\mathrm{l})} \rightarrow \mathrm{Fe}(\mathrm{OH})_{2(\mathrm{~s})}+\mathrm{H}_{2(\mathrm{~g})}$

$\mathrm{Fe}^{2+}$ and $\mathrm{Fe}^{3+}$ ions will immediately undergo further spontaneous reactions to create monomeric ions, ferric hydroxo complexes with hydroxide ions and polymeric species such as $\mathrm{Fe}(\mathrm{OH})_{2}^{4+}, \mathrm{Fe}(\mathrm{OH})_{2}^{+}, \mathrm{Fe}(\mathrm{OH})^{2+}, \mathrm{Fe}(\mathrm{OH})_{4}^{-}$, $\mathrm{Fe}\left(\mathrm{H}_{2} \mathrm{O}\right)_{2}^{+}, \quad \mathrm{Fe}\left(\mathrm{H}_{2} \mathrm{O}\right)_{5} \mathrm{OH}^{2+}, \quad \mathrm{Fe}\left(\mathrm{H}_{2} \mathrm{O}\right)_{8}(\mathrm{OH})_{2}^{4+}$, $\mathrm{Fe}_{2}\left(\mathrm{H}_{2} \mathrm{O}\right)_{6}(\mathrm{OH})_{4}^{2+}, \mathrm{Fe}\left(\mathrm{H}_{2} \mathrm{O}\right)_{4}(\mathrm{OH})_{2}^{+}, \mathrm{Fe}(\mathrm{OH})_{3}$ depending on the $\mathrm{pH}$ of the wastewater (Akyol 2012, Zaied and Bellakhal 2009). The formed gelatinous suspension of $\mathrm{Fe}(\mathrm{OH})_{\mathrm{n}(\mathrm{s})}$ that remains in the aqueous medium removes the waste matter from wastewater either by complex formation or by electrostatic attraction, followed by coagulation (Mollah et al. 2001).

In the present research that have been conducted throughout 2013 at Sharif University of Technology, Tehran, Iran, the effect of different parameters including $\mathrm{pH}$, time, voltage, supporting electrolyte, electrode material and initial diesel concentration on diesel and COD removal by EC was studied. Evaluation of all parameters which may affect the process was the primary aim of this research besides presenting and discussing sludge production and energy consumption data in order to achieve maximum potential of this process.

\section{Materials and methods}

In this study, synthetic wastewater was made and used in the EC setup (Fig. 1) by polluting water with different concentrations of diesel. The EC treatment was performed in a batch electrolytic reactor made from Plexiglas material. The EC cell consisted of three aluminum electrodes and three iron electrodes as cathodes and anodes. Total effective surface area of the electrodes was $6 \times 8 \times 10 \mathrm{~cm}^{2}$, and distance between each pair of electrodes was $2 \mathrm{~cm}$.

The EC cell was connected in monopolar parallel connection mode. In each run, 21 of wastewater was placed inside the EC reactor. Wastewater was mixed by a peristaltic pump (Heidolph, Germany), and the current density was adjusted by a digital DC power supply (IMV Corporation, Japan) operated at galvanostatic mode. Before each run, electrodes were washed by $\mathrm{HCl}$ solutions $(35 \%)$ and hexamethylenetetramine $(2.8 \%)$ to remove the oxide and passivation layers from the electrodes (Gengec et al. 2012). $\mathrm{HCl}$ solution $(0.1 \mathrm{~N})$ and $\mathrm{NaOH}$ solution $(0.1 \mathrm{~N})$ were used to adjust $\mathrm{pH}$. $\mathrm{NaCl}$ was used as an electrolyte, and all experiments were performed at room temperature $\left(25^{\circ} \mathrm{C}\right)$.

Samples were filtered after the experiment by a $1.6-\mu \mathrm{m}$ Whatman glass microfiber filter and then were analyzed. The initial and final COD concentrations were measured according to standard methods 5220D (Clesceri and Eaton 1998).

At the end of each EC experiment, the amount of formed sludge (metal hydroxide flocs together with removed pollutants) was determined by means of the total suspended solid measurements according to standard methods 2540D (Clesceri and Eaton 1998).

Diesel concentration was measured using UV-Vis spectrophotometry method, which previously used in Joint Danube Survey (2002). The only difference between current method and cited method is in measuring the UV absorbance using Unico-UV-2100 spectrophotometer at wavelength of $250 \mathrm{~nm}$ instead of $254 \mathrm{~nm}$ due to its highest absorbance among other wavelengths ranging from 220 to $300 \mathrm{~nm}$. In addition, diesel concentration and type of hydrocarbons were determined by GC-MS (Agilent Technologies-7890). The $\mathrm{pH}$ and conductivity of samples
Fig. 1 Schematic diagram of the EC cell

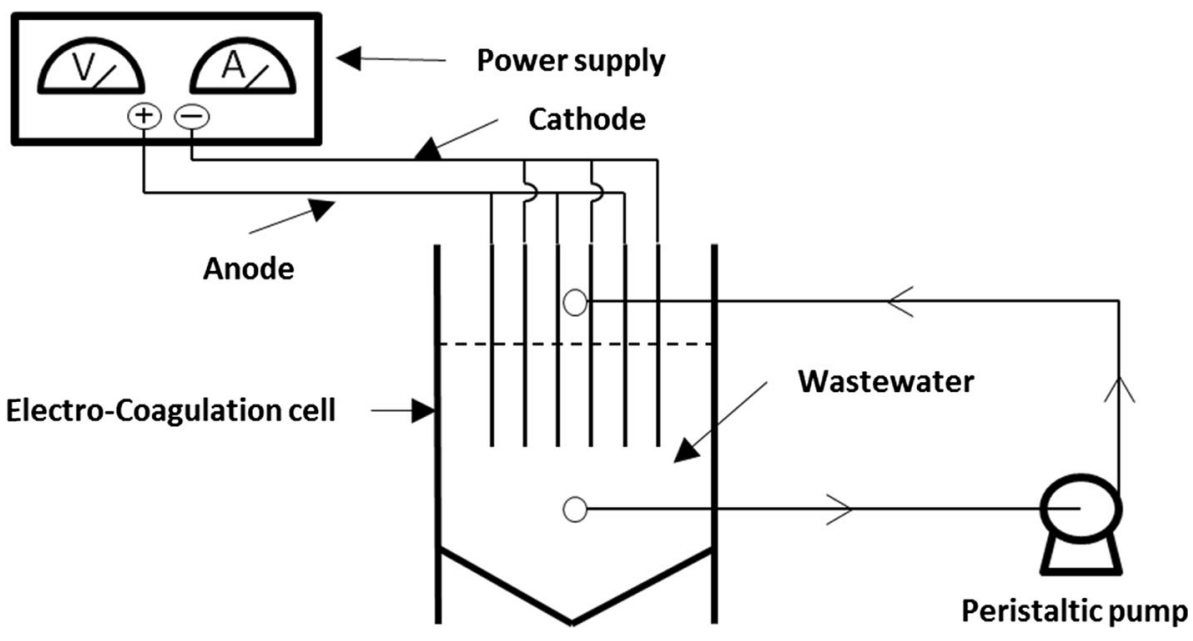


were measured using $\mathrm{pH}$ meter (HANNA $\mathrm{pH}$ 211) and conductometer (HACH-Sension7), respectively. All materials used were products of Merck Co., Germany.

Removal efficiency of the wastewater treated by EC was computed as follows:

Removal efficiency $=\frac{C_{0}-C_{\mathrm{e}}}{C_{0}} \times 100$

where $C_{0}$ is the initial concentration $(\mathrm{mg} / \mathrm{L})$ and $C_{\mathrm{e}}$ stands for concentration at any time $(\mathrm{mg} / \mathrm{L})$.

One of the most significant parameters that affect the application of any method of wastewater treatment is the cost. The operating cost in the EC process includes material (mainly electrode material), consumption of energy costs, labor, maintenance, sludge dewatering and disposal and fixed costs (Kobya et al. 2006). Consumption of energy cost is the major cost in the EC process; hence, this item was calculated. Consumption of energy $\left(\mathrm{kWh} / \mathrm{m}^{3}\right)$ was calculated using the following equation:

Energy Consumption $\left(\mathrm{kWh} / \mathrm{m}^{3}\right)=\frac{\text { V.I.t }}{\text { Treated volume }(l)}$

where $V$ is assigned as the cell voltage $(\mathrm{V}), I$ is the current (A) and $t$ represents the operating time (h).

The resistance on the electrode varies throughout the experiments. In order to achieve accurate results, current was monitored and weighted average of that is used for the calculations.

\section{Results and discussion}

The effect of several parameters including $\mathrm{pH}$, reaction time, voltage, electrode material, supporting electrolyte and the initial diesel concentration on the performance of EC in removing COD and diesel from synthetic wastewater was investigated. Also, the consumption of energy and the amount of sludge produced by this method were presented. The results are demonstrated and discussed below.

\section{Effect of pH on electrocoagulation}

The effect of $\mathrm{pH}$ on the removal efficiency of COD and diesel was investigated and is shown in Fig. 2a. It can be seen that the initial $\mathrm{pH}$ has a significant impact on the COD and diesel removal efficiency. The maximum removal efficiency of COD and diesel was observed at $\mathrm{pH}$ around 7. The removal efficiency of the COD and diesel in this $\mathrm{pH}$ region was $57.9 \pm 2.0$ and $52.1 \pm 1.5 \%$, respectively.

During the EC process, a pH increase is observed when the initial $\mathrm{pH}$ is acidic. The interpretation for this phenomenon is that this increase is due to the release of over-saturated $\mathrm{CO}_{2}$ because of hydrogen evolution at cathodes (Bazrafshan 2008; Chen et al. 2000; Kobya et al. 2006). It is also found that in the alkaline mediums, $\mathrm{pH}$ of the solution decreases through the treatment, which is due to precipitation of hydroxide ions with cations. These results show that EC can act as $\mathrm{pH}$ buffer.

The COD and diesel removal efficiencies decreased in acidic and alkaline conditions. This result can be explained by the distribution of iron ionic species. The species are useful for removal of pollutants, which are stable and insoluble. According to predominance zone diagram for iron (III) (Barrera-Diaz et al. 2003), at acidic conditions the species of $\mathrm{Fe}^{3+}, \mathrm{Fe}(\mathrm{OH})_{2}^{+}, \mathrm{Fe}(\mathrm{OH})^{2+}$ ions are dominant and at alkaline condition $\mathrm{Fe}(\mathrm{OH})_{4}^{-}$ion is dominant and these species are soluble; moreover, the solubility of $\mathrm{Fe}(\mathrm{OH})_{3(\mathrm{~s})}$ increases and these species are not effective for removal of $\mathrm{COD}$ and diesel. However, in neutral $\mathrm{pH}$, $\mathrm{Fe}(\mathrm{OH})_{3(\mathrm{~s})}$ is stable, insoluble and available for pollutant adsorption from wastewater. Thus, $\mathrm{Fe}(\mathrm{OH})_{3(\mathrm{~s})}$ has the major role in the removal of COD and diesel.

The constituents of hydrocarbon molecules are hydrophobic and nonpolar neutral; hence, they have probably been removed from the wastewater through the formation of surface complexes by gelatinous $\mathrm{Fe}(\mathrm{OH})_{3(\mathrm{~s})}$ precipitate. The active sites on hydrocarbon molecules complex present the surfaces of ferric hydroxide flocs which are growing (co-precipitation) and undergo physical adsorption onto the amorphous $\mathrm{Fe}(\mathrm{OH})_{3(\mathrm{~s})}$ flocs using van der Waals forces (Moussavi et al. 2011).

Based on the following reactions, the mechanism involved in the removal of petroleum hydrocarbons can be simplified (Moussavi et al. 2011): Formation of ferric hydroxide (at $6<\mathrm{pH}<9$ ):

$\mathrm{Fe}_{(\mathrm{aq})}^{3+}+3 \mathrm{OH}_{(\mathrm{aq})}^{-} \rightarrow \mathrm{Fe}(\mathrm{OH})_{3(\mathrm{~s})}$

Adsorption of hydrocarbons (HC):

$\mathrm{Fe}(\mathrm{OH})_{3(\mathrm{~s})}+\mathrm{HC} \rightarrow\left(\mathrm{Fe}(\mathrm{OH})_{3}-\mathrm{HC}\right)_{\text {floc }}$

$\left(\mathrm{Fe}(\mathrm{OH})_{3}-\mathrm{HC}\right)$ flocs can attach together and flocculate; thus, contaminants are separated from the wastewater by settling, flotation or filtration (Moussavi et al. 2011). This is consistent with the findings of Farhadi, et al. (Farhadi et al. 2012).

The effect of $\mathrm{pH}$ on the amount of sludge produced and consumption of energy is shown in Fig. 2b. By increasing $\mathrm{pH}$ from 3 to 11 , the amount of sludge formed increases from 448 to $496 \mathrm{mg} / \mathrm{L}$ and consumption of energy from 0.206 to $0.322 \mathrm{kWh} / \mathrm{m}^{3}$. Hence, at different initial $\mathrm{pHs}$, sludge production and consumption of energy were nearly constant. 

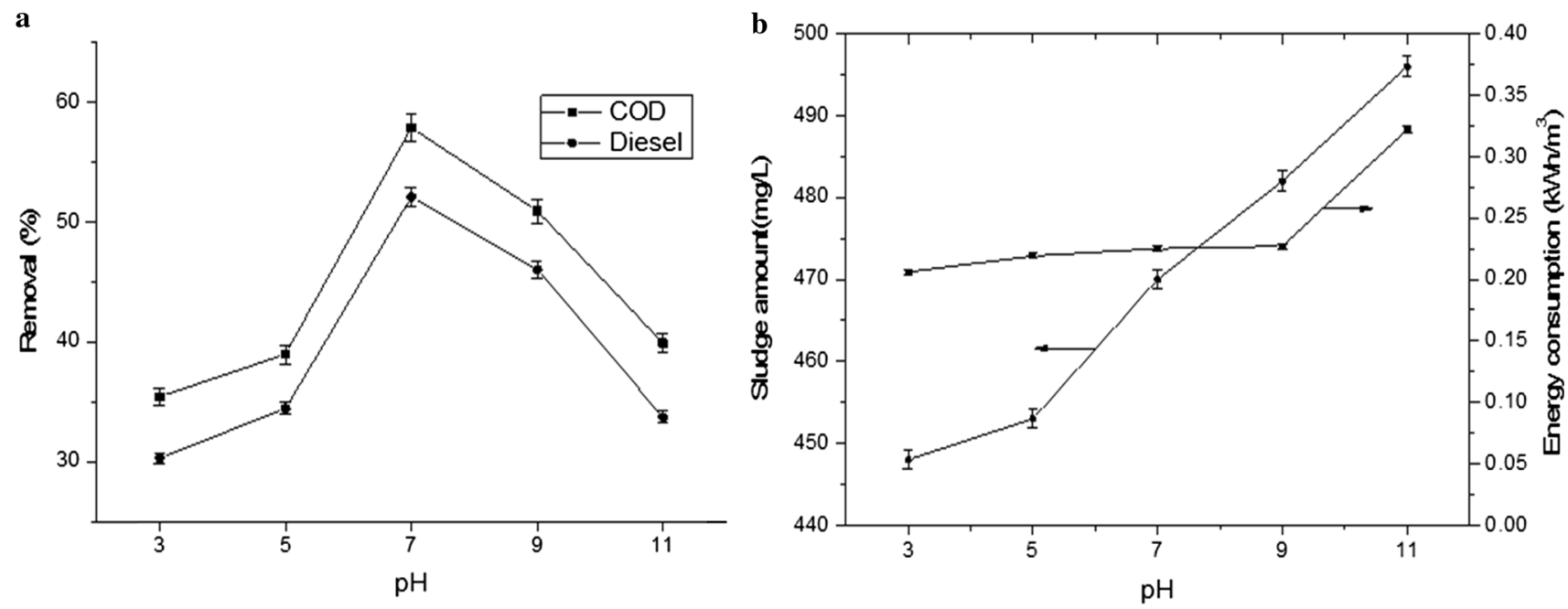

Fig. 2 a Effect of $\mathrm{pH}$ on the removal of COD and diesel and $\mathbf{b}$ effect of $\mathrm{pH}$ on the amount of sludge produced and consumption of energy (20 min, $4.5 \mathrm{~V}, \mathrm{NaCl}$ concentration of $0.5 \mathrm{~g} / \mathrm{L}, \mathrm{Fe}$-anode, Al-cathode, initial diesel concentration of $3500 \mathrm{mg} / \mathrm{L}$ )

\section{Effect of time on electrocoagulation}

The effect of time on the removal efficiency of COD and diesel in the EC process was investigated, and it is shown in Fig. 3a. The removal efficiencies of COD and diesel during the 60-min operation increased from $42.4 \pm 3.0$ to $85.0 \pm 3.4 \%$ and from $36.0 \pm 2.0$ to $82.03 .0 \%$, respectively. The removal efficiencies of the COD and diesel were nearly constant after $40 \mathrm{~min}$ of operating time. The removal efficiencies of the COD and diesel after $40 \mathrm{~min}$ were $83.3 \pm 2.3$ and $78.3 \pm 2.5 \%$, respectively.

Electrolysis time determines the rate of production of metal ions from electrodes. The COD and diesel removal efficiencies depend directly on the concentration of metal ions produced by the electrodes. That subject is justifiable by Faraday's law [Eq. (19)]. According to Faraday's law, theoretically, the amount of coagulant is directly proportional to the applied current to the electrolytic cell and time.

$C=\frac{M I t}{n F V}$

where $M, I, t, n, F$ and $V$ stand for molecular weight of metal ( $\mathrm{g} / \mathrm{mol})$, current $(\mathrm{A})$, time (s), metal valence ( 3 for $\mathrm{Al}$ and 2 for $\mathrm{Fe})$, Faraday constant $(96,500 \mathrm{C} / \mathrm{mol})$ and volume of wastewater, respectively (Kobya et al. 2010).

At the beginning of the EC process, the COD and diesel removal efficiencies are low since at initial times, the rate a

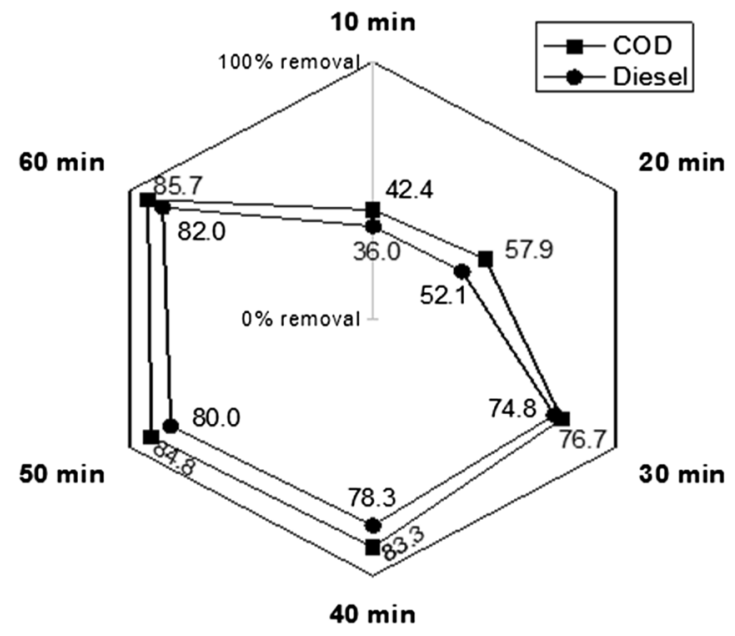

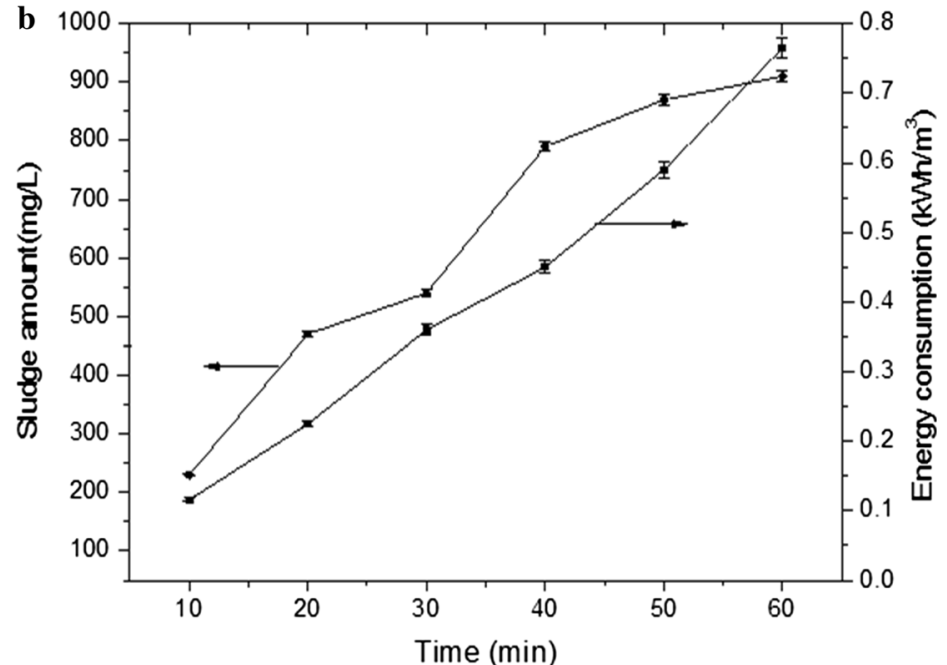

Fig. 3 a Effect of time on the removal of COD and diesel and $\mathbf{b}$ effect of time on the amount of sludge produced and consumption of energy (pH 7, $4.5 \mathrm{~V}, \mathrm{NaCl}$ concentration of $0.5 \mathrm{~g} / \mathrm{L}, \mathrm{Fe}$-anode, Al-cathode, initial diesel concentration of $3500 \mathrm{mg} / \mathrm{L}$ ) 
of production of metal ions from electrodes is low; however, when the electrolysis time increases, the concentration of metal ions and their hydroxide flocs increases; thus, the COD and diesel removal efficiencies increase. The removal efficiencies of the COD and diesel were nearly constant after $40 \mathrm{~min}$ of operating time since metal ions and their hydroxide flocs cover the electrode surface. Moreover, this has caused electrode passivation and the concentration of metal ions and their hydroxide flocs became constant; thus, the COD and diesel removal efficiencies did not change significantly. This is consistent with the findings of Chavalparit and Ongwandee (2009) that when operation time is increased, the removal efficiency is increased as well.

The effect of time on the amount of sludge produced and consumption of energy is shown in Fig. 3b. By increasing the time from $10 \mathrm{~min}$ to $60 \mathrm{~min}$, the sludge formation rate from 230 to $910 \mathrm{mg} / \mathrm{L}$ and consumption of energy from 0.116 to $0.765 \mathrm{kWh} / \mathrm{m}^{3}$ are increased.

The results have shown that sludge production and consumption of energy were proportional to time. According to Faraday's law [Eq. (19)], the amount of metal hydroxide formation and coagulant are directly proportional to time; thus, by increasing time, the produced sludge is increased. Furthermore, according to Eq. (16), consumption of energy is directly proportional to time; thus, by increasing time, consumption of energy is increased. In addition, the amount of sludge produced and consumption of energy increase by increasing the COD and diesel removal.

\section{Effect of voltage on electrocoagulation}

The voltage applied to the EC system determines the coagulant dosage rate. The effect of voltage on the removal efficiency of COD and diesel is shown in Fig. 4a. The removal efficiencies of COD and diesel are increased with the voltage $(4.5-10.5 \mathrm{~V})$ from $83.3 \pm 2.30$ to $96.9 \pm 1.2 \%$ and from $78.3 \pm 2.5$ to $96.8 \pm 1.0 \%$, respectively.

The applied voltage is an important parameter for the COD and diesel removal since it determines the coagulant dosage rate, concentration of metal ions and their hydroxide flocs. When voltage increases, the concentration of metal ions and their hydroxide flocs increase to absorb hydrocarbons. That subject is justifiable by Faraday's law [Eq. (19)]. Thus, the COD and diesel removal efficiencies are increased.

In addition to decreasing bubble size, the bubble generation rate increases with the increasing of voltage, which is beneficial for pollutants removal (Farhadi et al. 2012; Li et al. 2011). Since this has caused that the contact between hydroxide flocs and pollutants increases, the flotation process is improved and pollutants are rapidly removed.

The effect of voltage on the amount of sludge produced and consumption of energy is shown in Fig. 4b. By increasing the voltage from 4.5 to $10.5 \mathrm{~V}$, the sludge formation rate from 790 to $1930 \mathrm{mg} / \mathrm{L}$ and consumption of energy from 0.45 to $4.72 \mathrm{kWh} / \mathrm{m}^{3}$ are increased. The results have shown that sludge production and consumption of energy were proportional to voltage. According to Faraday's law [Eq. (19)], the amount of metal hydroxide formation and coagulant is directly proportional to voltage; thus, by increasing voltage, sludge produced is increased. According to Eq. (16), consumption of energy is directly proportional to voltage; thus, by increasing voltage, consumption of energy is increased. In addition, the amount of sludge produced and consumption of energy increase by increasing the COD and diesel removal.
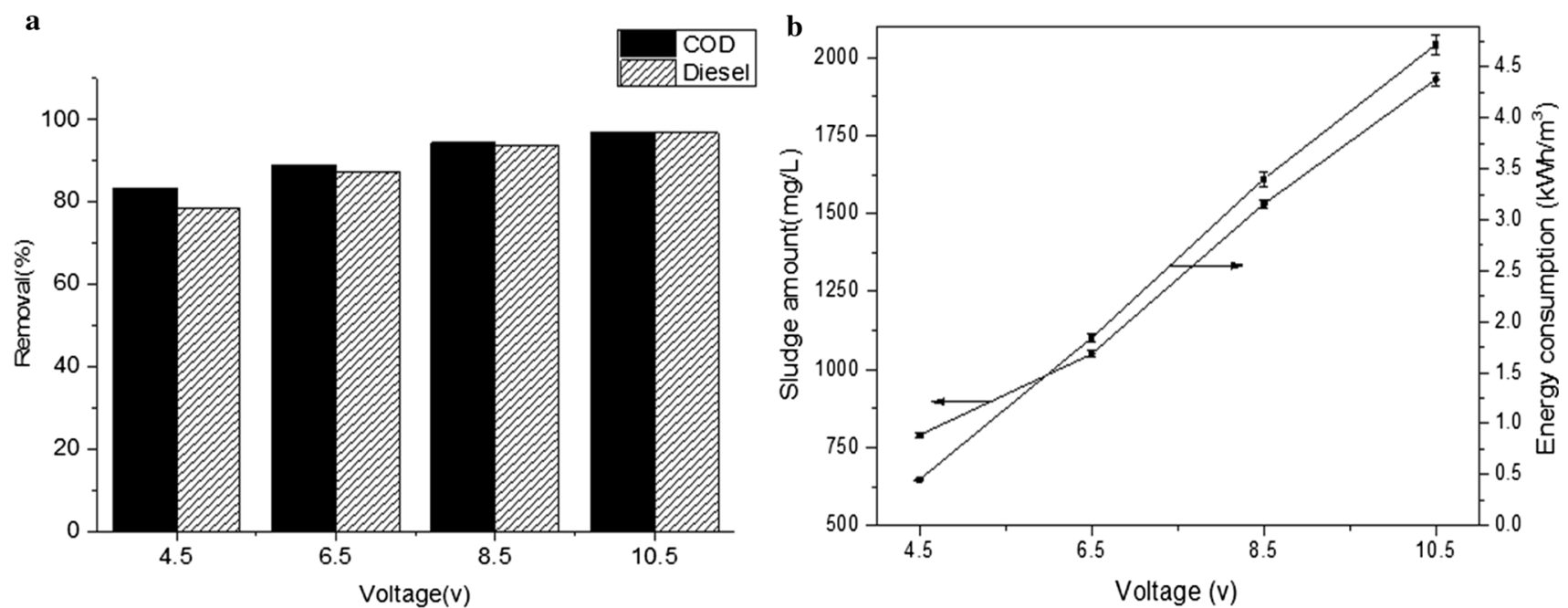

Fig. 4 a Effect of voltage on the removal of COD and diesel and $\mathbf{b}$ effect of voltage on the amount of sludge produced and consumption of energy ( $\mathrm{pH}$ 7, $40 \mathrm{~min}, \mathrm{NaCl}$ concentration of $0.5 \mathrm{~g} / \mathrm{L}, \mathrm{Fe}$-anode, Al-cathode, initial diesel concentration of $3500 \mathrm{mg} / \mathrm{L}$ ) 

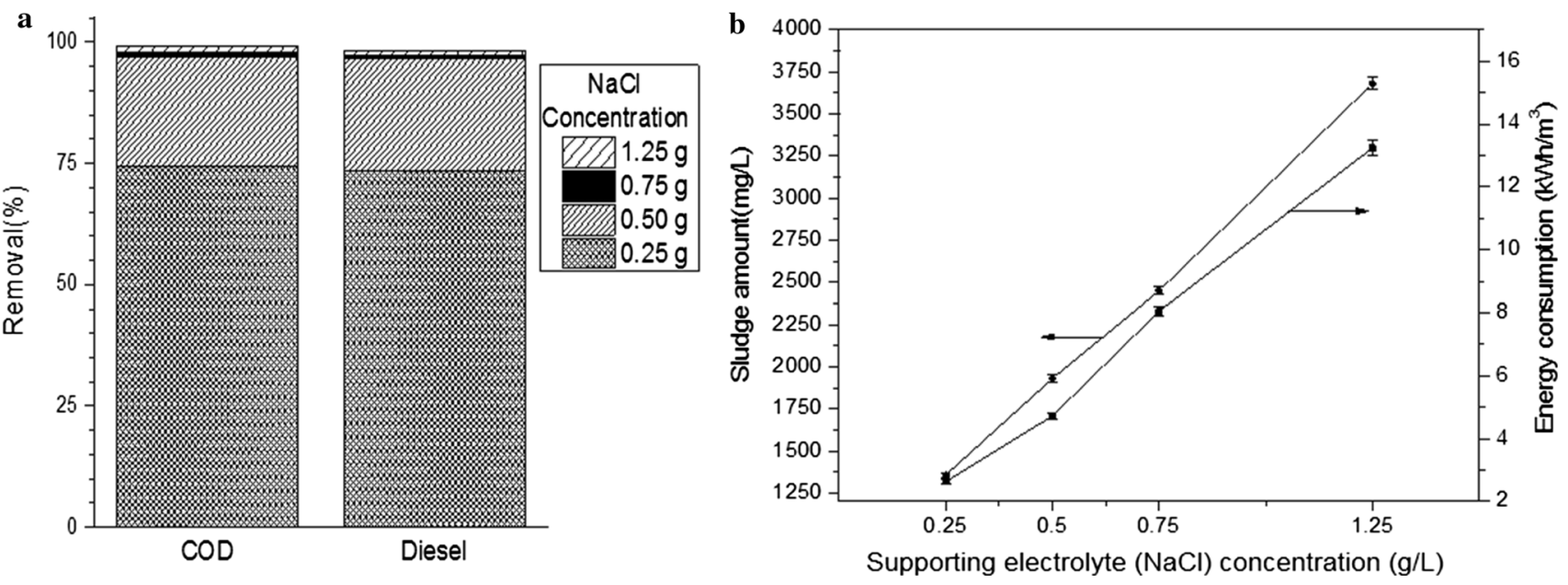

Fig. 5 a Effect of supporting electrolyte on the removal of COD and diesel and $\mathbf{b}$ effect supporting electrolyte concentration on the amount of sludge produced and consumption of energy ( $\mathrm{pH} \mathrm{7,} 40 \mathrm{~min}, 10.5 \mathrm{~V}, \mathrm{Fe}$-anode, Al-cathode, initial diesel concentration of $3500 \mathrm{mg} / \mathrm{L}$ )

\section{Effect of supporting electrolyte on electrocoagulation}

In this section, different sodium chloride concentrations were used to evaluate the effect of the solution conductivity on EC. It should be noted that the solution conductivity affects the cell voltage, current efficiency and consumption of energy in electrolytic cell (Daneshvar et al. 2006).

The effect of supporting electrolyte on the removal efficiency of COD and diesel is shown in Fig. 5a. $\mathrm{NaCl}$ concentration was set in the range from 0.25 to $1.5 \mathrm{~g} / \mathrm{L}$. The removal efficiency of COD and diesel was $96.9 \pm 1.2$ and $96.8 \pm 1.0 \%$, respectively, when $\mathrm{NaCl}$ concentration of the solution was $0.5 \mathrm{~g} / \mathrm{L}$. The removal efficiency was $99.1 \pm 0.5$ and $98.2 \pm 0.4 \%$ by adding $1.25 \mathrm{~g} / \mathrm{L}$ of NaCl . Hence, the experiments were conducted at $0.5 \mathrm{~g} / \mathrm{L}$ of $\mathrm{NaCl}$ due to negligible increase in removal. Moreover, almost no removal is observed without adding $\mathrm{NaCl}$ to the solution which is due to the fact that high electric conductivity is needed in order to use the EC's potential to remove the pollutants which synthetic oily wastewater does not possess it. This is in accordance with Yavuz et al. (2010) study.

$\mathrm{NaCl}$ solution was selected as an electrolyte since it has several advantages, i.e., chloride ions could significantly reduce the adverse effects of other anions, such as $\mathrm{HCO}_{3}^{-}$ and $\mathrm{SO}_{4}^{2-}$. The presence of the carbonate ion would lead to the precipitation of $\mathrm{Ca}^{2+}$ or $\mathrm{Mg}^{2+}$ ions that form an insulating layer on the surface of the electrodes. This insulating layer would sharply increase the ohmic resistance of the electrochemical cell and result in a significant reduction in the current efficiency and treatment conversion. Hence, it is suggested that among the present anions, there should be $20 \% \mathrm{Cl}^{-}$to ensure a normal operation of EC in water treatment (Parsa et al. 2011).
Conductivity causes an increase in current density; thus, more amount of coagulant can be introduced to the media. In addition, $\mathrm{NaCl}$ causes an increase in $\mathrm{Cl}^{-}$ions that chloride ions can remove the formed passivation layer on electrode surface (Chou et al. 2009). Thus, availability of metal hydroxide in the solution leads to an increase in the COD and diesel removal efficiency.

Molecular chlorine is produced during the electrolysis of chloride salts:

$2 \mathrm{Cl}^{-} \rightarrow \mathrm{Cl}_{2}+2 \mathrm{e}^{-}$

The produced molecular chlorine can then be hydrolyzed to hypochlorous acid and hypochlorite ions that these species are responsible for pollutants removal due to their high oxidative potentials (Janpoor et al. 2011).

$\mathrm{Cl}_{2(\mathrm{~g})}+\mathrm{H}_{2} \mathrm{O} \rightarrow \mathrm{HOCl}+\mathrm{H}^{+}+\mathrm{Cl}^{-}$

$\mathrm{HClO} \rightarrow \mathrm{ClO}^{-}+\mathrm{H}^{+}$

This is consistent with findings of (Abdelwahab et al. 2009) when supporting electrolyte increases during the operation as the removal efficiency is increased.

The effect of supporting electrolyte concentration on the amount of sludge produced and consumption of energy is shown in Fig. 5b. By increasing the supporting electrolyte concentration from 0.25 to $1.25 \mathrm{~g}$, the sludge formation rate from 1357 to $3680 \mathrm{mg} / \mathrm{L}$ and consumption of energy from 2.63 to $13.24 \mathrm{kWh} / \mathrm{m}^{3}$ are increased.

The results have shown that sludge production and consumption of energy were proportional to supporting electrolyte concentration. By increasing supporting electrolyte concentration, current and conductivity are increased during the process. Therefore, the amount of metal hydroxide formation, sludge production and consumption of energy are increased. In addition, the amount 
of sludge produced increases by increasing the COD and diesel removal.

\section{Effect of electrode material on electrocoagulation}

Aluminum and iron are cheap, available and proved to be effective; hence, they were applied in the current study. The effect of electrode material on the removal efficiency of COD and diesel is shown in Fig. 6a.

As demonstrated in Fig. 6a, the pollutants removal efficiency was over $95 \%$ for both electrode materials with an initial diesel concentration of $3500 \mathrm{mg} / \mathrm{L}$. The results reveal that the aluminum electrode as anode and cathode has the highest effect on reduction in the COD and diesel from wastewater.

Iron electrode as sacrificial anode appeared greenish at first resulting from $\mathrm{Fe}^{2+}$ ions and then turned into yellow resulting from $\mathrm{Fe}^{3+}$ ion in the effluent. During the electrolysis of iron electrode, $\mathrm{Fe}^{2+}$ is the common ion produced. It can be oxidized easily into $\mathrm{Fe}^{3+}$ using dissolved oxygen in water. Moreover, there is $\mathrm{Fe}^{3+}$ in yellow particles of $\mathrm{Fe}(\mathrm{OH})_{3}$, and it is difficult to be settled. Furthermore, iron electrode becomes corroded at open circuit; therefore, the iron electrode is not preferred. Furthermore, effluent with aluminum electrodes was found very clear and stable (Chen et al. 2000; Kobya et al. 2006).

Conductivity of aluminum electrode is more than iron electrode, which results in greater formation of coagulant of aluminum into the media. Hydroxide of aluminum is more stable than hydroxide of iron and also absorption strength of hydroxide of aluminum is more than hydroxide of iron. Hence, the aluminum electrode for anode and cathode is chosen comparing to other electrode sets.

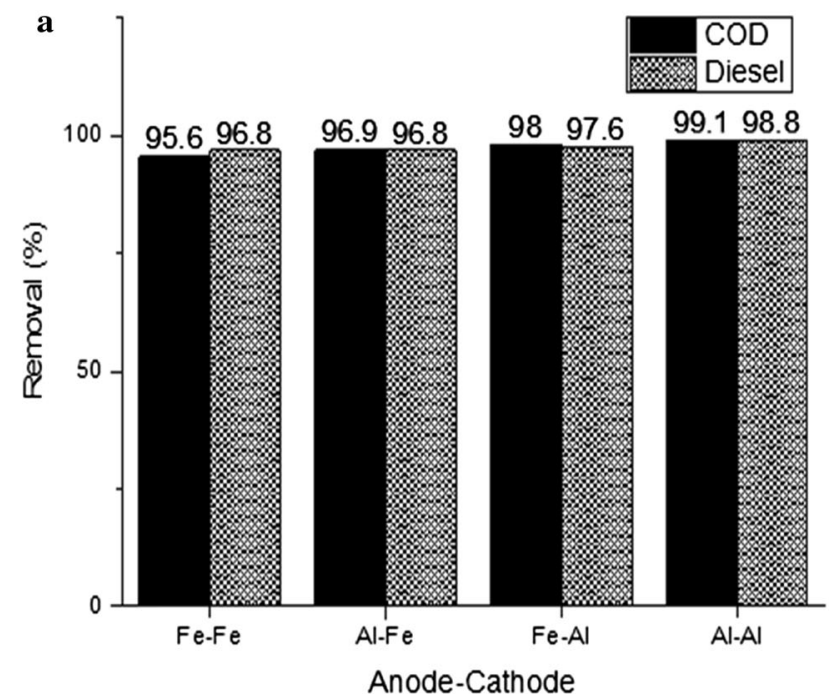

The effect of electrode material on the amount of sludge produced and consumption of energy is shown in Fig. 6b. The sludge formed and consumption of energy by aluminum electrode were more than the sludge formed and consumption of energy by iron electrode. As a result, the conductivity and coagulant formation by aluminum electrode are greater than iron electrode.

\section{Effect of initial diesel concentration on electrocoagulation}

The effect of initial diesel concentration was investigated from 3500 to $11,000 \mathrm{mg} / \mathrm{L}$, and the removal efficiencies of COD and diesel are shown in Fig. 7a. The COD and diesel removal was decreased from $99.1 \pm 0.2$ to $49.1 \pm 4.5 \%$ and from $98.8 \pm 0.2$ to $45.5 \pm 5.6 \%$, respectively, as the diesel concentration is increased from 3500 to $11,000 \mathrm{mg} / \mathrm{L}$.

Removal efficiency for higher concentration of diesel is lower compared to its lower concentrations when using the conditions, which are optimized for lower concentrations. Since the formation amounts of the coagulant are insufficient, the EC process needs more time and voltage to achieve the same removal efficiency as concentrations is lowered. This is consistent with the study of (Canizares et al. 2007) for the COD removal efficiency from breakup of oil-in-water emulsions. They observed that the COD removal efficiency was decreased when oil concentration is increased.

The results in Fig. $7 \mathrm{~b}$ have shown that sludge production and consumption of energy were proportional to the initial diesel concentration. By increasing the initial diesel concentration, current is increased during the process. Therefore, the amount of metal hydroxide formation, sludge production and consumption of energy are increased.

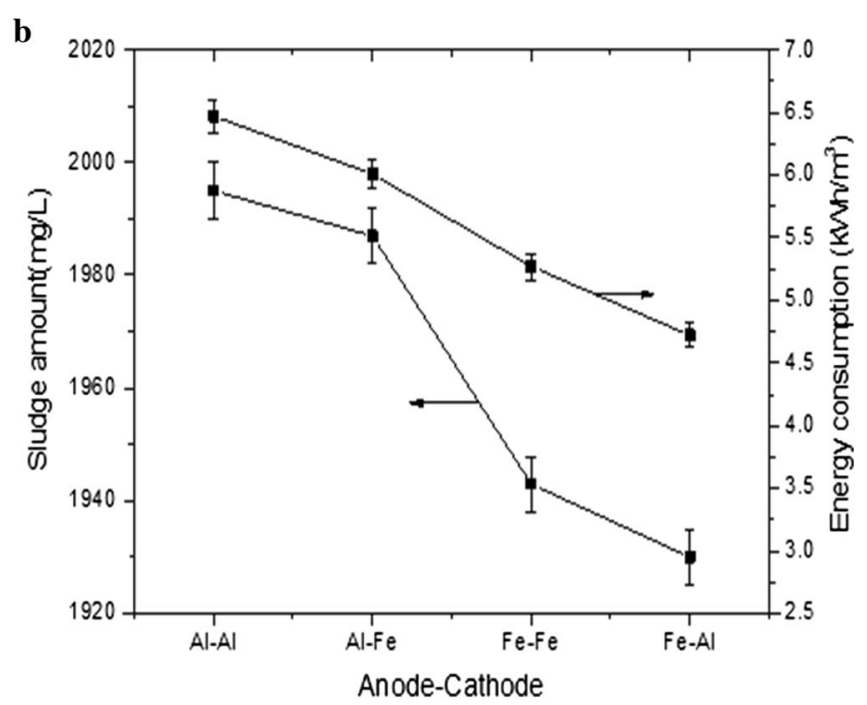

Fig. 6 a Effect of electrode material on the removal of COD and diesel and $\mathbf{b}$ effect electrode material on the amount of sludge produced and consumption of energy ( $\mathrm{pH} 7,40 \mathrm{~min}, 10.5 \mathrm{~V}, \mathrm{NaCl}$ concentration of $0.5 \mathrm{~g} / \mathrm{L}$, initial diesel concentration of $3500 \mathrm{mg} / \mathrm{L})$ 

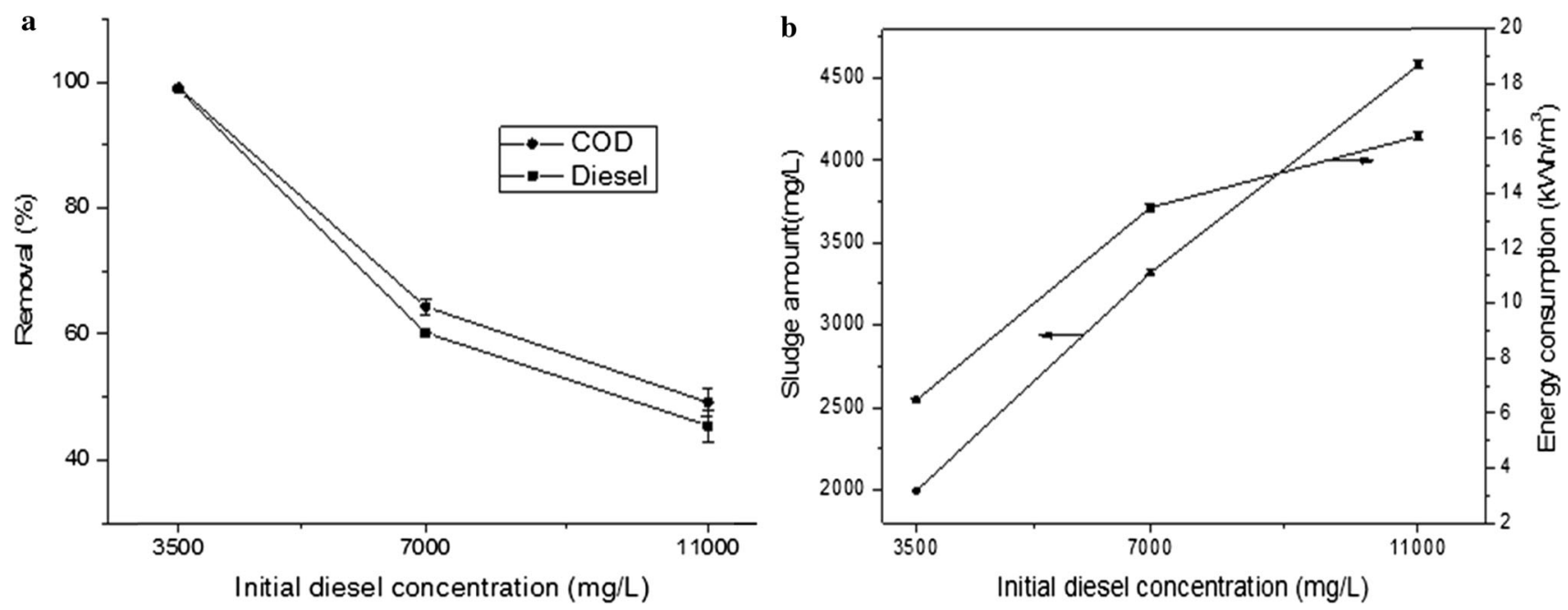

Fig. 7 a Effect of initial diesel concentration on the removal of COD and diesel and $\mathbf{b}$ effect of initial diesel concentration on the amount of sludge produced and consumption of energy ( $\mathrm{pH} 7,40 \mathrm{~min}, 10.5 \mathrm{~V}, \mathrm{NaCl}$ concentration of $0.5 \mathrm{~g} / \mathrm{L}, \mathrm{Al}$-anode, Al-cathode)

Summarily, the results have confirmed that sludge production and consumption of energy are proportional to voltage, time, the initial diesel concentration, as well as supporting electrolyte concentration; furthermore, there was a direct relationship between the amount of sludge formed and removal efficiency of the COD and diesel. In the optimal condition $(\mathrm{pH} 7,10.5 \mathrm{~V}, 40 \mathrm{~min}, \mathrm{NaCl}$ concentration of $0.5 \mathrm{~g} / \mathrm{L}, \mathrm{Al}$-anode, Al-cathode and the initial diesel concentration of $3500 \mathrm{mg} / \mathrm{L}$ ), the amount of sludge produced and the estimated consumption of energy were $1995 \mathrm{mg} / \mathrm{L}$ and $6.47 \mathrm{kWh} / \mathrm{m}^{3}$, respectively.

According to the Environmental Protection Agency (EPA), benchmark values for the COD and oil and Grease concentrations in stormwater are 120 and $15 \mathrm{mg} / \mathrm{L}$, respectively. COD and diesel concentrations in the optimal condition $(\mathrm{pH} 7,10.5 \mathrm{~V}, 40 \mathrm{~min}, \mathrm{NaCl}$ concentration of $0.5 \mathrm{~g} / \mathrm{L}, \mathrm{Al}$-anode, Al-cathode and initial diesel concentration of $3500 \mathrm{mg} / \mathrm{L}$ ) were 15 and $42 \mathrm{mg} / \mathrm{L}$, respectively. Thus, COD is below the limit recommended by EPA but further monitoring is required for oil and grease in order to ensure that the plant is successful in implementing Stormwater Pollution Prevention Plan (SWPPP) (EPA 2014). Even though the optimized EC process was not able to treat the diesel to its treatment limit, it was able to remove almost $99 \%$ of influent concentration; therefore, it can be used as a pretreatment for this type of wastewater.

\section{Determination of hydrocarbon types}

In the optimal condition $(\mathrm{pH} 7,10.5 \mathrm{~V}, 40 \mathrm{~min}, \mathrm{NaCl}$ concentration of $0.5 \mathrm{~g} / \mathrm{L}, \mathrm{Al}$-anode, Al-cathode and initial diesel concentration of $3500 \mathrm{mg} / \mathrm{L}$ ), the samples were analyzed by the GC-MS to determine the types of hydrocarbons. The types of hydrocarbons and their removal efficiency are shown in Table 1.
Chromatogram of hydrocarbons before and after the treatment is illustrated in Fig. 8. As shown, nearly all hydrocarbons were removed.

\section{Results' comparison with previous studies}

1. One of the main advantages of EC is that short treatment time is required in comparison with other treatment methods. For instance, (Lohi et al. 2008) used threephase fluidized bed reactor to achieve removal efficiency of $90 \%$ for COD which took several days; however, in this research, EC method is used to achieve removal efficiency of $99 \%$ for COD in $40 \mathrm{~min}$.

2. The oil removal from oily wastewater by (Tir and MoulaiMostefa 2008) has been achieved under this condition $\left(t<20 \mathrm{~min}\right.$, current density $25 \mathrm{~mA} / \mathrm{cm}^{2}$ and $\left.\mathrm{pH} 7\right)$ and led to $90 \%$ COD removal. (Ben Hariz et al.2013) used this condition $\left(t=30 \mathrm{~min}\right.$, current density $21.2 \mathrm{~mA} / \mathrm{cm}^{2}$ and $\mathrm{pH} 9)$ to remove $80 \%$ of the COD. However, in the present study, under this condition ( $t=40 \mathrm{~min}$, current density $3.125 \mathrm{~mA} / \mathrm{cm}^{2}$ and $\mathrm{pH} \mathrm{7)} 99 \%$ of the COD is removed. Hence, the present study is able to achieve higher removal rate in more time and less current density.

3. Yavuz et al. (2010) have used EC to treat the refinery wastewater. Using iron electrode at current density of $1 \mathrm{~mA} / \mathrm{cm}^{2}$ and $120 \mathrm{~min}$ time, $2.26 \%$ of the COD is removed ; however, in the present study, by optimizing other parameters such as $\mathrm{pH}$, voltage, electrode material and supporting electrolyte concentration over $2 \log$ removal of COD has been achieved.

4. According to Asselin's results in Table 2 (Asselin et al. 2008), it can be concluded that by using aluminum electrode in the present study at the same current and less time, higher removal efficiency, less sludge production and consumption of energy have achieved. 
Table 1 Identified compounds and their removal efficiency

\begin{tabular}{|c|c|c|c|}
\hline Time (min) & Compound & Hydrocarbon group & Removal efficiency $(\%)$ \\
\hline 7.829 & Nonane & Alkane & 95 \\
\hline 9.587 & Benzene, 1-ethyl-3-methyl- & Aromatic & 100 \\
\hline 10.476 & 1,2,4-Trimethylbenzene & Aromatic & 100 \\
\hline 10.668 & n-Decane & Alkane & 100 \\
\hline 11.228 & Oxalic acid, 2-ethylhexyl nonyl ester & Polycyclic aromatic & 100 \\
\hline 13.165 & Undecane & Alkane & 97 \\
\hline 15.886 & Isododecane & Alkane & 99 \\
\hline 18.162 & Naphthalene, 1-methyl- & Polycyclic aromatic & 99 \\
\hline 19.952 & Dodecane, 2,6,11-trimethyl- & Branched alkanes & 98 \\
\hline 20.428 & Tetradecane & Alkane & 95 \\
\hline 21.579 & Nonadecane & Alkane & 97 \\
\hline 22.210 & Pentadecane & Alkane & 97 \\
\hline 23.701 & Cetane Hexadecane & Alkane & 98 \\
\hline 24.355 & Octacosane & Alkane & 100 \\
\hline 24.621 & Trimethylsilyl ether of glycerol & Ether & 100 \\
\hline 25.000 & Heptadecane & Alkane & 99 \\
\hline 25.078 & Hexadecane, 2,6,11,15-tetramethyl- & Branched alkanes & 99 \\
\hline 26.182 & Heptadecane & Alkane & 100 \\
\hline 26.292 & Hexadecane, 2,6,10,14-tetramethyl- & Alkane & 100 \\
\hline 27.268 & Octacosane & Alkane & 100 \\
\hline 28.282 & Pentadecane & Alkane & 100 \\
\hline 29.281 & Furazan-3-carboxamide, oxime, 4-amino-N,N-dimethyl- & Aromatic & 99 \\
\hline
\end{tabular}

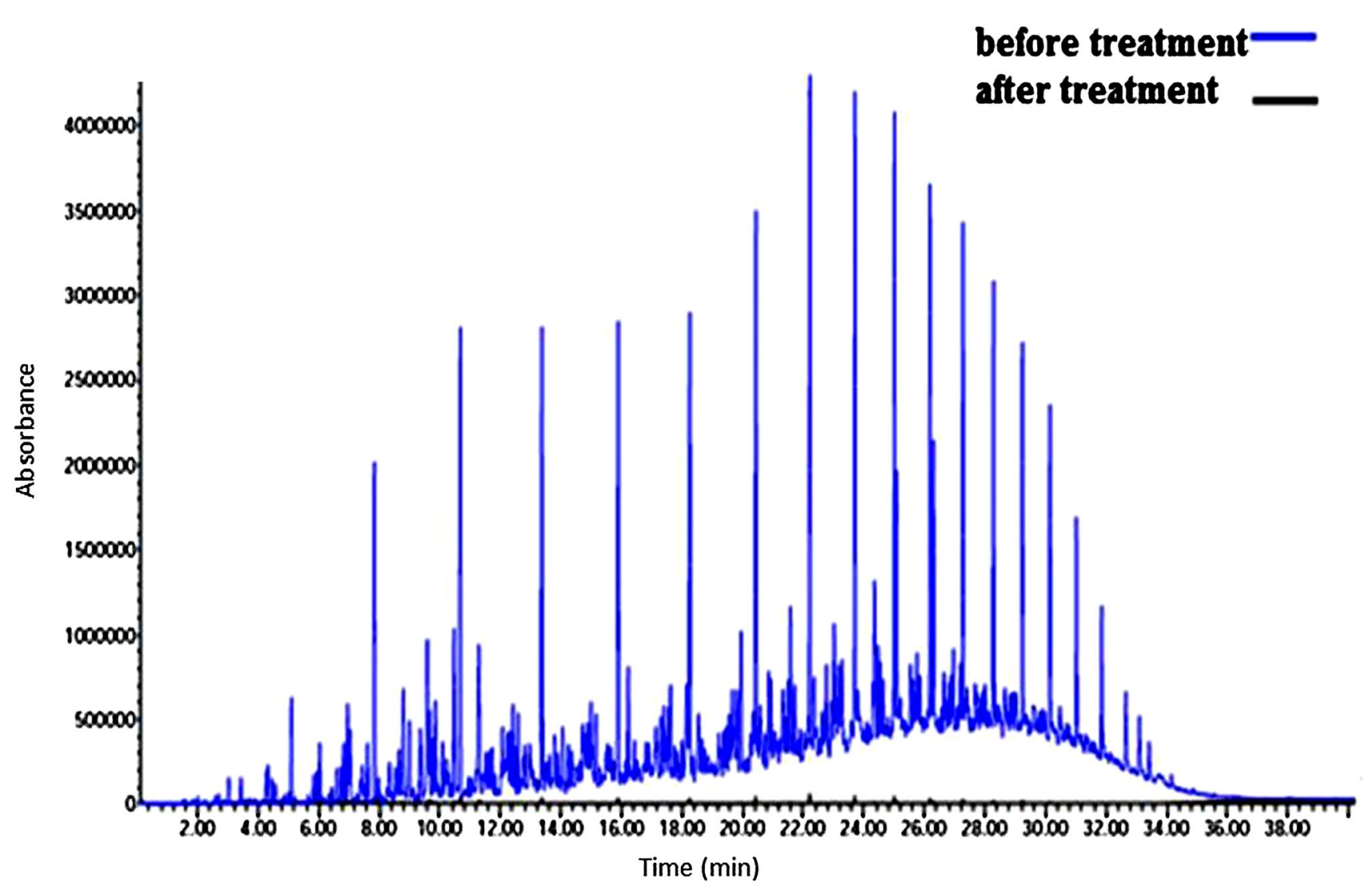

Fig. 8 Chromatogram of hydrocarbon before and after treatment by electrocoagulation 
Table 2 Asselin's results compared to the current study

\begin{tabular}{|c|c|c|c|c|c|c|c|}
\hline $\begin{array}{l}\text { Electrode } \\
\text { material }\end{array}$ & $\begin{array}{l}\text { Current } \\
\text { (A) }\end{array}$ & $\begin{array}{l}\text { Voltage } \\
\text { (V) }\end{array}$ & $t(\min )$ & $\begin{array}{l}\text { Consumption of energy } \\
(\mathrm{kWh} / \mathrm{m} 3)\end{array}$ & $\begin{array}{l}\text { Sludge production } \\
(\mathrm{kg} / \mathrm{m} 3)\end{array}$ & $\begin{array}{l}\text { COD removal } \\
(\%)\end{array}$ & References \\
\hline $\mathrm{Al}$ & 1.8 & 10.5 & 40 & 6.47 & 1995 & 99.1 & In this article \\
\hline $\mathrm{Al}$ & 2 & 4.3 & 90 & 7.5 & 4940 & 74.7 & $\begin{array}{l}\text { (Asselin et al. } \\
\text { 2008) }\end{array}$ \\
\hline $\mathrm{Fe}$ & 1.5 & 10.5 & 40 & 5.27 & 1943 & 95.6 & In this article \\
\hline $\mathrm{Fe}$ & 1.5 & 3.1 & 90 & 4.04 & 2780 & 73.8 & $\begin{array}{l}\text { (Asselin et al. } \\
\text { 2008) }\end{array}$ \\
\hline
\end{tabular}

5. El-Naas et al. have achieved 63 and $42 \%$ removal for samples with initial COD concentrations of 596 and $4050 \mathrm{mg} / \mathrm{L}$, respectively. Their results are achieved in $60 \mathrm{~min}$ time, $\mathrm{pH} 8$, current density of $30 \mathrm{~mA} / \mathrm{cm}^{2}$, but in the present study, higher removal rate in less time and less current density have been achieved (El-Naas et al. 2009). Current results are in accordance with El-Naas results which removal efficiency is decreased by increasing the COD; however, in high COD the removal amount is higher. In addition, present results are compatible with (El-Naas et al. 2009) considering the use of aluminum as the most effective type of electrode.

\section{Conclusion}

In the current study, removal of COD and diesel from oily wastewater was investigated using electrocoagulation. The results of this study demonstrated that EC could be successfully used to remove the COD and diesel from synthetic wastewater contaminated by diesel. The effects of different parameters such as $\mathrm{pH}$, time, voltage, supporting electrolyte, electrode material and diesel initial concentration on the treatment of this wastewater in a batch EC reactor were investigated.

According to this study, the $\mathrm{pH}$ has a considerable effect on the COD and diesel removal. The optimal initial $\mathrm{pH}$ for current experiments was 7 . In addition, the $\mathrm{pH}$ of the wastewater was nearly constant during the process due to the buffering effect of the EC. The electrode arrangement of $\mathrm{Al}-\mathrm{Al}$ as anode-cathode achieved the highest efficiency in reducing the COD and diesel. Increase in the voltage, time and $\mathrm{NaCl}$ concentration resulted in increase in removal efficiency, sludge production and consumption of energy. There was almost no removal for COD and diesel when no $\mathrm{NaCl}$ is added to the solution which is due to low conductivity of synthetic oily wastewater. Augmentation in the initial diesel concentration decreases the COD and diesel removal efficiencies but increases the sludge production and consumption of energy.

According to EPA, EC effluent of this study $(15 \mathrm{mg} / \mathrm{L}$ $\mathrm{COD}$ and $42 \mathrm{mg} / \mathrm{L}$ diesel) is in compliance with discharge regulations for COD, but further diesel removal is required in order to discharge current wastewater into aquatic medium. However, EC is a promising process for pretreatment of oily wastewater. Furthermore, the buffering effect of the EC process allows the wastewater to be discharged without $\mathrm{pH}$ adjustments.

In summary, the highest removal efficiency for treating oily wastewater using EC was observed at $\mathrm{pH} 7,40 \mathrm{~min}$, $10.5 \mathrm{~V}, \mathrm{NaCl}$ concentration of $0.5 \mathrm{~g} / \mathrm{L}$, aluminum as anode and cathode material, and initial diesel concentration of $3500 \mathrm{mg} / \mathrm{L}$. In the optimized conditions, removal rates of $99.1 \pm 0.2 \%$ for the COD and $98.8 \pm 0.2 \%$ for the diesel are achieved. Moreover, the amount of sludge produced and energy consumption were $1995 \mathrm{mg} / \mathrm{L}$ and $6.47 \mathrm{kWh} /$ $\mathrm{m}^{3}$, respectively.

Acknowledgments The authors would like to acknowledge the Sharif University of Technology for financial and instrumental supports.

\section{References}

Abdelwahab O, Amin NK, El-Ashtoukhy ESZ (2009) Electrochemical removal of phenol from oil refinery wastewater. J Hazard Mater 163:711-716

Akyol A (2012) Treatment of paint manufacturing wastewater by electrocoagulation. Desalination 285:91-99

Amani-Ghadim AR, Aber S, Olad A, Ashassi-Sorkhabi H (2013) Optimization of electrocoagulation process for removal of an azo dye using response surface methodology and investigation on the occurrence of destructive side reactions. Chem Eng Process 64:68-78

Asselin M, Drogui P, Brar SK, Benmoussa H, Blais JF (2008) Organics removal in oily bilgewater by electrocoagulation process. J Hazard Mater 151:446-455

Azadi Aghdam M, Kariminia H-R, Safari S (2015) Removal of lignin, $\mathrm{COD}$, and color from pulp and paper wastewater using electrocoagulation. Desalin Water Treat. doi:10.1080/ 19443994.2015.1040461

Barrera-Diaz C, Urena-Nunez F, Campos E, Palomar-Pardave M, Romero-Romo M (2003) Combined electrochemical-irradiation treatment of highly colored and polluted industrial wastewater. Radiat Phys Chem 67:657-663

Bazrafshan E (2008) Performance evaluation of electrocoagulation process for removal of chromium (VI) from synthetic chromium solutions using iron and aluminum electrodes. Turk J Eng Env Sci 32:59-66 
BEN Hariz I, HALLEB A, ADHOUM N, MONSER L (2013) Treatment of petroleum refinery sulfidic spent caustic wastes by electrocoagulation. Sep Purif Technol 107:150-157

Bensadok K, Benammar S, Lapicque F, Nezzal G (2008) Electrocoagulation of cutting oil emulsions using aluminium plate electrodes. J Hazard Mater 152:423-430

Canizares P, Martinez F, Lobato J, Rodrigo MA (2007) Break-up of oil-in-water emulsions by electrochemical techniques. J Hazard Mater 145:233-240

Chafi M, Gourich B, Essadki AH, Vial C, Fabregat A (2011) Comparison of electrocoagulation using iron and aluminium electrodes with chemical coagulation for the removal of a highly soluble acid dye. Desalination 281:285-292

Chavalparit O, Ongwandee M (2009) Optimizing electrocoagulation process for the treatment of biodiesel wastewater using response surface methodology. J Environ Sci China 21:1491-1496

Chen XM, Chen GH, Yue PL (2000) Separation of pollutants from restaurant wastewater by electrocoagulation. Sep Purif Technol 19:65-76

Chou WL, Wang CT, Chang SY (2009) Study of COD and turbidity removal from real oxide-CMP wastewater by iron electrocoagulation and the evaluation of specific energy consumption. J Hazard Mater 168:1200-1207

Clesceri LSG, Eaton AE (1998) Standard Methods for the Examination of Water and Wastewater. APHA American Public Health Association, Washington D.C

Daneshvar N, Khataee AR, Djafarzadeh N (2006) The use of artificial neural networks (ANN) for modeling of decolorization of textile dye solution containing C. I. Basic Yellow 28 by electrocoagulation process. J Hazard Mater 137:1788-1795

El-Naas MH, Al-Zuhair S, Al-Lobaney A, Makhlouf S (2009) Assessment of electrocoagulation for the treatment of petroleum refinery wastewater. J Environ Manage 91:180-185

EPA 2014. Secondary treatment regulation; 40 CFR part 133 and 149. In: REGULATION, C. O. F. (ed.) title 40

Farhadi S, Aminzadeh B, Torabian A, Khatibikamal V, Fard MA (2012) Comparison of COD removal from pharmaceutical wastewater by electrocoagulation, photoelectrocoagulation, peroxi-electrocoagulation and peroxi-photoelectrocoagulation processes. J Hazard Mater 219:35-42

Gendel Y, Lahav O (2010) A new approach to increasing the efficiency of low-pH Fe-electrocoagulation applications. J Hazard Mater 183:596-601

Gengec E, Kobya M, Demirbas E, Akyol A, Oktor K (2012) Optimization of baker's yeast wastewater using response surface methodology by electrocoagulation. Desalination 286:200-209

Irdemez S, Demircioglu N, Yildiz YS (2006) The effects of pH on phosphate removal from wastewater by electrocoagulation with iron plate electrodes. J Hazard Mater 137:1231-1235

Janpoor F, Torabian A, Khatibikamal V (2011) Treatment of laundry waste-water by electrocoagulation. J Chem Technol Biotechnol 86:1113-1120

Karhu M, Kuokkanen V, Kuokkanen T, Ramo J (2012) Bench scale electrocoagulation studies of bio oil-in-water and synthetic oilin-water emulsions. Sep Purif Technol 96:296-305

Katal R, Pahlavanzadeh H (2011) Influence of different combinations of aluminum and iron electrode on electrocoagulation efficiency: application to the treatment of paper mill wastewater. Desalination 265:199-205

Khoufi S, Feki F, Sayadi S (2007) Detoxification of olive mill wastewater by electrocoagulation and sedimentation processes. J Hazard Mater 142:58-67

Kobya M, Can OT, Bayramoglu M (2003) Treatment of textile wastewaters by electrocoagulation using iron and aluminum electrodes. J Hazard Mater 100:163-178
Kobya M, Hiz H, Senturk E, Aydiner C, Demirbas E (2006) Treatment of potato chips manufacturing wastewater by electrocoagulation. Desalination 190:201-211

Kobya M, Demirbas E, Dedeli A, Sensoy MT (2010) Treatment of rinse water from zinc phosphate coating by batch and continuous electrocoagulation processes. J Hazard Mater 173:326-334

LI XD, SONG JK, GUO JD, WANG ZC, FENG QY (2011) Landfill leachate treatment using electrocoagulation. In: 3rd International conference on Environmental science and information application technology esiat 2011, Vol 10, Pt B, 10, pp 1159-1164

Liska I (2002) Final report of the joint Danube survey. In: international commission for the protection of the Danube River (ICPDR), pp 157-170

Lohi A, Cuenca MA, Anania G, Upreti SR, Wan L (2008) Biodegradation of diesel fuel-contaminated wastewater using a three-phase fluidized bed reactor. J Hazard Mater 154:105-111

Mollah MYA, Schennach R, Parga JR, Cocke DL (2001) Electrocoagulation (EC)—science and applications. J Hazard Mater 84:29-41

Moussavi G, Khosravi R, Farzadkia M (2011) Removal of petroleum hydrocarbons from contaminated groundwater using an electrocoagulation process: batch and continuous experiments. Desalination 278:288-294

Parsa JB, Vahidian HR, Soleymani AR, Abbasi M (2011) Removal of Acid Brown 14 in aqueous media by electrocoagulation: optimization parameters and minimizing of energy consumption. Desalination 278:295-302

Phalakornkule C, Polgumhang S, Tongdaung W, Karakat B, Nuyut T (2010) Electrocoagulation of blue reactive, red disperse and mixed dyes, and application in treating textile effluent. J Environ Manage 91:918-926

Rasheed QJ, Pandian K, Muthukumar K (2011) Treatment of petroleum refinery wastewater by ultrasound-dispersed nanoscale zero-valent iron particles. Ultrason Sonochem 18:1138-1142

Sengil IA, Ozacar M (2006) Treatment of dairy wastewaters by electrocoagulation using mild steel electrodes. J Hazard Mater 137:1197-1205

Sun Y, Zhang YB, Quan X (2008) Treatment of petroleum refinery wastewater by microwave-assisted catalytic wet air oxidation under low temperature and low pressure. Sep Purif Technol 62:565-570

Tchamango S, Nanseu-Njiki CP, Ngameni E, Hadjiev D, Darchen A (2010) Treatment of dairy effluents by electrocoagulation using aluminium electrodes. Sci Total Environ 408:947-952

Tir M, Moulai-Mostefa N (2008) Optimization of oil removal from oily wastewater by electrocoagulation using response surface method. J Hazard Mater 158:107-115

Verma A, Wei XP, Kusiak A (2013) Predicting the total suspended solids in wastewater: a data-mining approach. Eng Appl Artif Intell 26:1366-1372

Wan W, Pepping TJ, Banerji T, Chaudhari S, Giammar DE (2011) Effects of water chemistry on arsenic removal from drinking water by electrocoagulation. Water Res 45:384-392

Yavuz Y, Koparal AS, Ogutveren UB (2010) Treatment of petroleum refinery wastewater by electrochemical methods. Desalination 258:201-205

Yilmaz AE, Boncukcuoglu R, Kocakerim MM, Kocadagistan E (2008) An empirical model for kinetics of boron removal from boron-containing wastewaters by the electrocoagulation method in a batch reactor. Desalination 230:288-297

Zaied M, Bellakhal N (2009) Electrocoagulation treatment of black liquor from paper industry. J Hazard Mater 163:995-1000

Zhu BT, Clifford DA, Chellam S (2005) Comparison of electrocoagulation and chemical coagulation pretreatment for enhanced virus removal using microfiltration membranes. Water Res 39:3098-3108 